\title{
Economic Contribution of Home-stay in Nepal
}

\author{
Indra Bahadur Malla Thakuri \\ PhD Scholar, Mewar University, Rajasthan, India \\ Email: ibmalla@hotmail.com
}

\begin{abstract}
Home-stay is new model of tourism development in Nepal which provides an excellent opportunity to share, see and feel the diverse countryside lifestyle, local culture, and tradition. It promotes the rural economy through the promotion of rural tourism. The article aims to assess the economic contribution of home-stay entities of Nepal, based on the descriptive and exploratory design. Data were collected from the 102 home-stay entities of Lamjung, Tanahu and Nawalparasi districts. Statistical result shows that there is a significant increase in income and expenditure of local people in all sample study areas. It is found that majority of respondents have managed their household expenditure from the income of home-stay entities. The income status of Nawalparasi district is better than in the other two districts whereas the expenditure of Tanahu district is higher than in the other two districts. It indicates the better economic status of Nawalparasi district. All home-stay operators have reported the increment in their savings, which directly contributes to the improvement in their economic status. However, it is also found that there is a need to improve the quality of service to increase the flow of local and foreign tourists to increase the income of home-stay operators.
\end{abstract}

\section{KEYWORDS}

Contribution, Economic, Home-stay, Nepal

\section{INTRODUCTION}

Tourism industry is not a new phenomenon. It can be traced to the period of human origin. The nature of travelling activities may vary, however, it was from the early period in search of food and appropriate habitation. Ranjit (1976) states that noticeably there are differences between modern and past travelling. But it is the habit of travelling which has originated the growth of this industry. The variance of travelling in the past and modern is between surviving and desire. Ranjit further opines that travelling in those far off days was a must for the survival and existence of early men. But with the dawn of civilization and change in the human stance, the meaning of travelling has been shifted from the necessity to the desire of taking splendid journeys (1976, p. 17).

A paying guest at one's home for short period is a home-stay tourist. The service related to such tourist is called home-stay tourism. But such guests are provided accommodation and services by individual family as well as community too. Thus, the home-stay directive has accepted it as managed by an individual or community (Timalsina, 2012). The home-stay seeks to draw tourists away from posh and crowded urban areas to the rural locality full of splendid 
natural surroundings, by providing them with clean, comfortable and budget-friendly accommodation and food. Thus, home-stay offers the traveler a unique local experience and possibilities of interaction with the host family. It offers the chance to experience new and untapped places which has enabled the government to popularize new tourist destinations, and provide alternative source of income to the rural folks (Gangotia, 2013, p. 206). In home-stay tourism, visitors get a chance to spend time with the family observing their customs, values and culture, which give them the opportunity to feel the taste of rural life (Devkota, 2010). Culturalheritage and its geographical structure make Nepal one of the famous destinations for home-stay tourism.

In home-stay tourism, both the environment and culture are commoditized; market value is created with the demand of visitors. It provides financial reward to the local indigenous community for conservation of the environment and their culture (Laurie \& Radcliffe, 2005). Under this approach, tourism is considered to be a component of development, giving emphasis to explore ways of expanding positive impacts and reducing negative impacts. Home-stay tourism is a major player when it comes to the reduction of rural poverty. It integrates all activities of tourism such as trekking, cultural tourism, agro-tourism, health tourism, and ecotourism (Devkota, 2010). It is a good source of earning foreign currency. It reduces the gap in the balance of payment, provides increased tax revenue, gives rise to economic development of the nation, and increases the employment opportunities. It may also provide new markets for local people to sell their products, such as agricultural products, livestock and others (Budhathoki, 2013). Growth in tourism motivates people to pursue higher education and to obtain new jobs, and it thus also increases the literacy rate. It provides opportunities for new generations to redefine and reclaim their cultural and ethnic identity. The villagers and other concerns were given trainings in hospitality and basic guiding skills to the local residents to provide them the opportunity to learn about hygiene, tourism and conservation techniques.

There are different categories of impacts of tourism industry. According to Kreag (2000) economic impacts, impacts on environment, impacts on social and cultural patterns, overcrowding impacts, impacts on the rendered services, impacts on the state and local taxes and impacts on the attitudes of the community are major seven impacts of tourism industry. The tourism industry has both positive as well as negative impacts. The tourism industry increases income, increases tax profits, improvement of infrastructure, increases gross national products, etc. (Perdue, Long, \& Allen, 1987). Considering the important contribution of tourism in nation building, the study aims to explore the economic contribution of home-stay in community development. Home-stay is one important part to promote the rural tourism. In Nepalese context, home-stay has significant role to promote the tourism.

\section{MATERIALS AND METHOD}

The study was based on the descriptive as well as exploratory research design which gives the economic contribution of home-stay entities as well as its effect on the lifestyle of home-stay operators. The study was conducted in the Lamjung, Tanahu and Nawalparasi districts 
of Nepal. Data was collected from the 102 home-stay entities. Purposive sampling was used to select the household because of the limited numbers of home-stay entities in the study areas. Structured questionnaire was used to collect the data. The quantitative data was analyzed through the statistical methods: frequency, mean, correlation and ANOVA.

\section{RESULT AND DISCUSSION}

The data was collected from the 102 home-stay entities of selected three districts and out of the total respondents $49.0 \%$ male and $51.0 \%$ female participated in survey. It was found that $98 \%$ indigenous people were operating the home-stay entities. The mean age of home-stay operators was 39 Yrs with minimum 18 Yrs to maximum 70 Yrs. Besides, the study collected the data related to the economic status and contribution of home-stay entities.

\section{Daily Income of Home-stay operators}

Income is one major indicator of economic status of people. Operation of home-stay is one of the best option for the self-employment which become the source of earning and contribution for rural tourism. There is home-stay association which gives guidelines about the service quality and cost of services. There is more or less similar standard of service in all home-stay. Community people were asked about their daily income from home-stay entities. It was found that people earn minimum NRs 100 and maximum NRs 600 as daily income with average income as NRs 175.25. For vegetarian food they charge minimum NRs 280 and maximum NRs 860. The average income was NRs 514.22, for non- vegetarian food with lodging was minimum NRs 500 and maximum NRs 1100 and average income was NRs 707.75.

Table 1: Daily Income of Home-stay Operators

\begin{tabular}{|l|l|l|l|l|l|}
\hline \multicolumn{7}{|c|}{ Descriptive Statistics } \\
\hline Categories & $\begin{array}{l}\text { Number of } \\
\text { respondents }\end{array}$ & $\begin{array}{l}\text { Minimum } \\
\text { income NRs. }\end{array}$ & $\begin{array}{l}\text { Maximum } \\
\text { Income NRs. }\end{array}$ & $\begin{array}{l}\text { Mean } \\
\text { Income } \\
\text { NRs. }\end{array}$ & Std. Deviation \\
\hline Lodging only & 102 & 100 & 600 & 175.25 & 88.615 \\
\hline Veg. food + Lodging & 102 & 280 & 860 & 514.22 & 132.362 \\
\hline Non-veg. food + Lodging & 102 & 500 & 1100 & 707.75 & 174.798 \\
\hline
\end{tabular}

Source: Field Survey, 2016

Income of home-stay operator depends on the expenditure capacity of tourists. Tourists spend money on the basis of service facilities as well as their purpose of visit. The previous studies have measured the contribution of tourism in Nepalese economy. Berger (1978) in his PhD. thesis, the central theme was to define the importance of tourism and its various economic benefits to Nepal; and the main objectives were to analyze the impact of tourism on Nepalese economy. The major findings of the study were: tourism plays an important role in the Nepalese economy- as the increase in the volume of tourist flow has direct as well as indirect impacts on the development process of Nepal, tourism is effective and promising instrument for earning 
foreign exchange, it requires heavy investment from public and private sector while providing relatively few jobs and offering limited scope for the improvement of personal and regional income distribution. The study explored tourist arrivals and tourist expenditure, the per capita gross tourist expenditure was found increasing rapidly from NRs127 in 1962-63 to NRs 3339 in 1978-79 and further to NRs 5659 in 1981. Seasonality factor was found the most prominent in Nepalese tourism. Average per capita tourist expenditure per day was found varying. Nearly 8087 percent tourists were found visiting Nepal for pleasure trips. The study suggested developing tourism to the extent that foreign exchange is needed for development purposes but to concentrate society's resource in other fields where benefits of development are shared more widely (Berger, 1978).

Similarly, Shrestha (1998) also stated that Nepal is extremely rich in tourism products and it exists all over the country. Natural wealth, cultural and monumental heritage, bequeathed history are the principal tourism products of Nepal. Nepal possesses tremendous diversities to develop it as a major tourist destination from various perspectives. In view of the present status of infrastructures, significant attention has to be paid to avail and improve facilities in order to develop the existing tourism areas as well as develop potential areas within and outside of Kathmandu valley. Nepal has not been able to earn as per the growth of visitors or compared to market potential. Nepal earns one of the lowest per day spending by tourist. Despite it, tourism is a major source of foreign exchange of Nepal and it is playing an important role in the national economy. Tourism has generated significant indirect benefits through the growth of allied industrial sector and boosting export trade. Moreover, tourism helps to promote balanced regional development of the country as well. Hence the contribution of tourism in the socioeconomic development of Nepal is very significant.

\section{Daily Expenditure of Home-stay Operators}

Net profit depends upon the level of income and expenditure so management always try to increase the income level and decrease the expenditure. The main objective of this article is to know the economic benefit from the home stay so the home-stay operators were asked about their daily expenditure on lodging and food item prepared in home-stay for tourist. It was found that expenditure for only lodging was minimum NRs 60 and maximum NRs175 and average expenditure was NRs119.75. Lodging with veg food was minimum NRs 200 and maximum was NRs 850 and average expenditure was NRs 441.67.

Table 2: Daily Expenditure of Home-stay Operators

\begin{tabular}{|l|l|l|l|l|l|}
\hline \multicolumn{7}{|c|}{ Descriptive Statistics } \\
\hline Categories & $\begin{array}{l}\text { Number of } \\
\text { Participants }\end{array}$ & $\begin{array}{l}\text { Minimum } \\
\text { Exp. in NRs }\end{array}$ & $\begin{array}{l}\text { Maximum } \\
\text { Exp. in NRs }\end{array}$ & $\begin{array}{l}\text { Mean } \\
\text { Exp. in NRs }\end{array}$ & Std. Deviation \\
\hline Lodging only & 102 & 60 & 175 & 119.75 & 26.582 \\
\hline Veg food + Lodging & 102 & 200 & 850 & 441.67 & 151.573 \\
\hline Non-veg food + Lodging & 102 & 250 & 850 & 517.16 & 222.694 \\
\hline
\end{tabular}

Vol. 3. No. III

www.phdcentre.edu.np 
Source: Field Survey, 2016

Lodging with non-veg food item was minimum NRs 250 and maximum NRs 850 and average expenditure was NRs 517.16. The price (rate) of home-stay is very affordable in comparison to its service quality. Home-stay operators always use the local product and mobilize the local resources to entertain the tourist so that it does not cost very high for their goods and services. It provides the pure homely environment and shares the typical local culture so the foreign have good opportunity to learn the local tradition and culture in very rural setting. The loving and caring of home-stay promotes the rural tourism which attracts the tourist. Income of home-stay will be increased with the increment of tourist.

\section{Monthly Income, Expenditure and Net Profit of Home-stay}

Daily income and expenditure determines the monthly income and expenditure. Similarly, it also determines the net monthly income. As people were asked about their monthly income, expenditure and net profit of home-stay, they answered for monthly income was minimum NRs 12000 and maximum NRs 40000 and average income was NRs 23053.92. And for monthly expenditure was minimum NRs 2500 and maximum NRs 25000 and average expenditure per month was NRs 13279.41.

Table 3: Monthly Income, Expenditure and Net Profit of Home-stay

\begin{tabular}{|l|l|l|l|l|l|}
\hline \multicolumn{9}{|c|}{ Descriptive Statistics } \\
\hline Categories & $\begin{array}{l}\text { Number of } \\
\text { Participants }\end{array}$ & $\begin{array}{l}\text { Minimum } \\
\text { Amt. in NRs }\end{array}$ & $\begin{array}{l}\text { Maximum } \\
\text { Amt. in NRs }\end{array}$ & $\begin{array}{l}\text { Mean } \\
\text { Amt. in NRs }\end{array}$ & Std. Deviation \\
\hline Monthly income & 102 & 12000 & 40000 & 23053.92 & 7604.775 \\
\hline Monthly expenditure & 102 & 2500 & 25000 & 13279.41 & 2792.887 \\
\hline Net monthly income & 102 & 3000 & 30000 & 12265.69 & 7835.047 \\
\hline
\end{tabular}

Source: Field Survey, 2016

Net monthly income was minimum NRs 3000 and maximum NRs 30000 with average net monthly income was NRs 12265.69. The data shows that income level is higher than the expenditure which clearly indicates the level of net profit from home-stay. In the local context of Nepalese society, the average monthly income NRs 25000-30000 remains good to manage household expenditure. Rural life is comparatively easier than the urban life; expenditure is comparatively less in rural life. There is no very expensive market in rural society so people can save their income. Saving amount directly contribute in improvement of livelihood than the total income so the data reports the positive contribution of income of home-stay in economic life of home-stay operators in study areas.

\section{Relation between the Income and Expenditure of Home-stay}

The study measures the relationship between income and expenditure. There is effect of income in expenditure and saving capacity of people. The result shows the relationship between the income and expenditure but there is moderate level negative correlation. 
Table 4: Relation between the Income and Expenditure of Home-stay

\begin{tabular}{|c|c|c|c|}
\hline \multicolumn{4}{|c|}{ Correlations } \\
\hline & & Monthly income & Monthly expenditure \\
\hline \multirow{3}{*}{$\begin{array}{l}\text { Monthly } \\
\text { income from } \\
\text { home-stay }\end{array}$} & Pearson Correlation & 1 & $-.376^{* *}$ \\
\hline & Sig. (2-tailed) & & .000 \\
\hline & $\mathrm{N}$ & 102 & 102 \\
\hline \multirow{3}{*}{$\begin{array}{l}\text { Monthly } \\
\text { expenditure to } \\
\text { home-stay }\end{array}$} & Pearson Correlation & $-.376^{* *}$ & 1 \\
\hline & Sig. (2-tailed) & .000 & \\
\hline & $\mathrm{N}$ & 102 & 102 \\
\hline
\end{tabular}

Source: Field Survey, 2016

The statistical analysis of correlation found that there was significant correlation between income and expenditure of home-stay because the $\mathrm{P}=.000$ which is less than .05 significant level. The Pearson Correlation is -.376. Negative correlation indicates that if one point increase in income then expenditure decreased by .376 points. From the economic perspective, it is good for saving of income. If expenditure will be decreased then it contributes in increment of saving.

\section{Analysis of Variance on Income and Expenditure of Home-stay}

The study covered the three sites of three districts. The geographic location and development facilities are different in study areas so it may cause the income and expenditure of home stay. Considering differences in location, the study analyzed the variance of mean of income and expenditure within and between the groups. The analysis of variance (ANOVA) found that there was significant different in monthly income of all selected home-stay of all three districts with $\mathrm{F}$ $=96.992$ and $\mathrm{P}=.000$. Similarly, there was significant different in monthly expenditure of all selected home-stay of all three districts with $\mathrm{F}=6.973$ and $\mathrm{P}=.001$.

Table 5: Analysis of Variance on Income and Expenditure of Home-stay

\begin{tabular}{|l|l|r|r|r|r|r|}
\hline \multicolumn{7}{|c|}{ ANOVA } \\
\hline \multirow{2}{*}{$\begin{array}{l}\text { Monthly } \\
\text { Income }\end{array}$} & Sum of Squares & df & Mean Square & F & Sig. \\
\cline { 2 - 8 } & Within Groups & 3867377817.616 & 2 & 1933688908.808 & 96.992 & .000 \\
\cline { 2 - 8 } & Total & 5841093431.373 & 101 & & & \\
\hline $\begin{array}{l}\text { Monthly } \\
\text { Expenditure }\end{array}$ & Between Groups & 97277240.896 & 2 & 48638620.448 & 6.973 & .001 \\
\cline { 2 - 8 } & Within Groups & 690544523.810 & 99 & 6975197.210 & & \\
\hline
\end{tabular}




\begin{tabular}{|l|l|l|l|l|l|l|}
\hline & Total & 787821764.706 & 101 & & & \\
\hline
\end{tabular}

Source: Field Survey, 2016

The statistical result of F-test rejected the null hypothesis which assumed no relationship because the result shows the significant difference in monthly income and expenditure among the all three study districts. It indicates that on the basis of geographical setting and infrastructure facilities, the income and expenditure become different in study areas.

\section{Comparative Analysis of Income and Expenditure}

The statistical analysis F-test shows the significant different of income and expenditure among the three study districts. Further, the comparative analysis shows that one to one relationship of each district. The result shows that there was significant difference between the Lamjung and Nawalparasi districts because the $\mathrm{P}=.000$ but Nawalparasi district has the significantly higher value than in Lamjung district. Similarly, there was significant difference between the Nawalparasi and Tanahu districts because of $\mathrm{P}=.000$ but Nawalparasi district has higher value than in Tanahu district. However, Tanahu and Lamjung districts has significant difference because $\mathrm{P}=.000$ but Lamjung district has higher value than in Tanahu district.

Table 6: Comparative Analysis of Income and Expenditure by Sample Area

\begin{tabular}{|c|c|c|c|c|c|c|c|c|}
\hline \multicolumn{9}{|c|}{ Comparative Analysis } \\
\hline \multirow{2}{*}{$\begin{array}{l}\text { Depen } \\
\text { dent } \\
\text { Varia } \\
\text { ble }\end{array}$} & \multirow[t]{2}{*}{$\begin{array}{l}\text { (I) } \\
\text { District }\end{array}$} & \multirow[t]{2}{*}{ (J) District } & \multirow{2}{*}{\begin{tabular}{|l} 
Mean \\
Difference \\
$(\mathrm{I}-\mathrm{J})$
\end{tabular}} & \multirow[t]{2}{*}{ Std. Error } & \multirow[t]{2}{*}{ Sig. } & \multicolumn{2}{|c|}{$\begin{array}{l}95 \% \text { Confidence } \\
\text { Interval }\end{array}$} & \multirow{2}{*}{ Remarks } \\
\hline & & & & & & $\begin{array}{l}\text { Lower } \\
\text { Bound }\end{array}$ & $\begin{array}{l}\text { Upper } \\
\text { Bound }\end{array}$ & \\
\hline \multirow{3}{*}{ 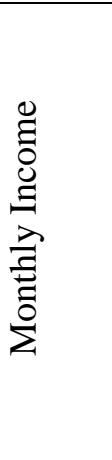 } & Lamjung & $\begin{array}{l}\text { Nawalparas } \\
\mathrm{i}\end{array}$ & $-6684.259^{*}$ & 1112.116 & .000 & -8890.94 & $\begin{array}{l}- \\
4477.58\end{array}$ & $\begin{array}{l}\text { Nawalparasi has } \\
\text { higher value than } \\
\text { Lamjung }\end{array}$ \\
\hline & $\begin{array}{l}\text { Nawalpar } \\
\text { asi }\end{array}$ & Tanahu & $15690.688^{*}$ & 1143.680 & .000 & 13421.38 & $\begin{array}{l}17960.0 \\
0\end{array}$ & $\begin{array}{l}\text { Nawalparasi has } \\
\text { higher value than } \\
\text { Tanahu }\end{array}$ \\
\hline & Tanahu & Lamjung & $-9006.429^{*}$ & 1033.454 & .000 & $\begin{array}{l}- \\
11057.03\end{array}$ & - 6955.83 & $\begin{array}{l}\text { Lamjung has } \\
\text { higher value than } \\
\text { Tanahu }\end{array}$ \\
\hline \multirow{3}{*}{ 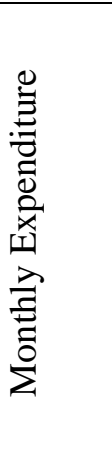 } & Lamjung & $\begin{array}{l}\text { Nawalparas } \\
\mathrm{i}\end{array}$ & $2427.778^{*}$ & 657.815 & .000 & 1122.53 & 3733.03 & $\begin{array}{l}\text { Lamjung has } \\
\text { higher value than } \\
\text { Nawalparasi }\end{array}$ \\
\hline & $\begin{array}{l}\text { Nawalpar } \\
\text { asi }\end{array}$ & Tanahu & $-1763.492^{*}$ & 676.485 & .011 & -3105.79 & -421.20 & $\begin{array}{l}\text { Tanahu has } \\
\text { higher value than } \\
\text { Nawalparasi }\end{array}$ \\
\hline & Tanahu & Lamjung & -664.286 & 611.287 & .280 & -1877.21 & 548.64 & $\begin{array}{l}\text { Tanahu has } \\
\text { higher value than } \\
\text { Lamjung }\end{array}$ \\
\hline
\end{tabular}


*. The mean difference is significant at the 0.05 level. Source: Field Survey, 2016

In case of monthly expenditure, there was the significant difference between Lamjung and Nawalparasi districts with $\mathrm{P}=.000$ and Lamjung district has higher value than in Nawalparasi district. Again in Nawalparasi and Tanahu districts, there was significant difference with $\mathrm{P}$ $=.000$. The individual value indicates that Tanahu district has higher value than in Nawalparasi district. Similarly, there was significant difference between Tanahu and Lamjung districts with $\mathrm{P}$ $=.280$. In comparison, Tanahu district has higher value than in Lamjung district.

The income level of Nawalparasi district is comparatively higher than in the other two districts whereas the expenditure is higher in Tanahu district than in the other two districts. It indicates that the economic contribution of home-stay is better in Nawalparasi district than in the other two districts. The reason may be that the Nawalparasi district is located in the plain region which is accessible from transportation and other utilities. Cost of production and transportation is comparatively low in plain region than in other hilly region so the expenditure may be lower than other regions. It is also known that well compliance of standard of home-stay and quality service determine the income and expenditure status so the findings suggest to charge the service cost on the basis of geographical setting as well as available infrastructures and mobilization of local resources.

\section{Managing the Household Expenditure from Income of Home-stay}

Rural tourism is one source of income for the rural people. Nepal is rich for natural beauty and cultural diversity so people of different country visit Nepal. The home-stay operators are contributing in promotion of local beauty and resources. It has significant contribution in change and development of rural community. It is a way of self-employment and source of income generating activity. The study found the satisfactory level of income from home-stay so in this connection, home-stay operators were asked about the sufficiency of income to manage the household expenditure. The data shows that the respondents of Lamjung district out of $41.1 \%$ (39) respondents, $28.4 \%$ (27) respondents reported that they managed their household expenditure well from the income of home-stay followed by $10.5 \%$ (10) reported normal and $2.1 \%$ (2) reported unable to manage from the income to housekeeping. Similarly, in Nawalparasi district out of $28.4 \%$ (27) respondents, $12.6 \%$ ( 12) reported manage well and 12.6\% (12) normal and $3.2 \%$ (3) unable to manage the housekeeping.

Table 7: Managing the Household Expenditure from Income of Home-stay

\begin{tabular}{|l|l|l|l|l|l|l|}
\hline \multicolumn{2}{|c|}{} & \multicolumn{3}{|c|}{$\begin{array}{c}\text { Managing household expenditure from } \\
\text { home-stay income }\end{array}$} & \multirow{2}{*}{ Total } \\
\cline { 3 - 6 } & Managed well & Normal & Not managed & \\
\hline District & Lamjung & Count & 27 & 10 & 2 & 39 \\
\hline
\end{tabular}


ISSN: 2362-1303 (Paper) | elSSN: 2362-1311(Online)

JOURNAL OF ADVANCED ACADEMIC RESEARCH (JAAR)

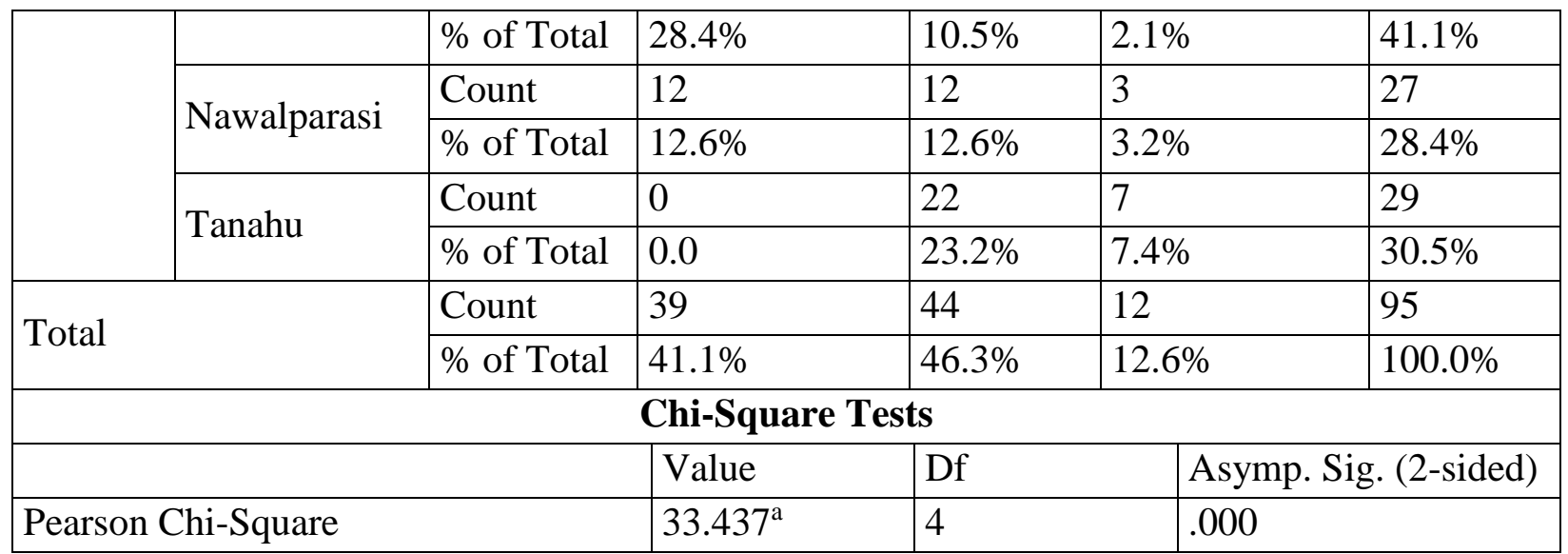

Source: Field Survey, 2016

Likewise, in Tanahu district out of 30.5\% (29) respondents, $23.2 \%$ (22) reported normal and $7.4 \%$ (7) reported unable to manage the household expenditure from income of home-stay. Thus, in total, $41.1 \%$ (39) managed well followed by $46.3 \%$ (44) in normal mode and $12.6 \%$ (12) were unable to manage the household expenditure from annual income of home-stay. Still, around $13 \%$ home-stay operators reported the problem to manage the household from the income of home-stay so there is need to find out the better way to improve the quality service of home-stay and strategy to promote local tourism. Some internal infrastructure and quality service of homestay and other external environmental factors may be the cause of not earning good amount from the home-stay so problem should be identified and need to be improved. Home-stay not only enhanced the socio-economic status of individual but also improve the social status so problem of each home-stay should be seriously cared from the concerned stakeholders and individual.

The statistical analysis of Pearson Chi-Square test showed that there was significant association between the all three districts regarding the managing the household expenditure from the income of home-stay business because the $\mathrm{P}=.000$ which is less than .05 significant levels.

\section{CONCLUSION}

The study measured the level of income and expenditure of home-stay operators as well as its relationship. Income is relatively higher than the expenditure and correlation test shows the moderate level negative relation between the income and expenditure which indicate the increment of saving. Improved economic status is directly associated with the saving capacity of people. The income status of Nawalparasi district was higher than other two districts whereas expenditure was higher in Tanahu district than in other districts. Nawalparasi district is located in the plain region whereas Tanahu and Lamjung districts are located in hilly region. Nawalparasi district is very accessible and have infrastructure and other service facilities with comparatively low price than in the other districts. So, it is the reason to be better economic status than in other districts. It shows that the economic status of home-stay operators of Nawalparasi district was 
better than in the other districts. Income of home-stay operators was enough to manage the basic expenditure of daily household, health and education of their children. Economically, home-stay has provided the opportunity for marketing of other local products as well as created the opportunity of self-employment. There was need to monitor the compliance of basic standard of home-stay developed by the Nepal Government. Quality service can support to increase the number of tourists in rural tourism.

\section{REFERENCES}

Berger, V. (1978). The Economic Impact of Tourism in Nepal: An Input- Output Analysis. Cornel University.

Budhathoki, B. (2013). Impact of homestay tourism on livelihood : a case study of Ghale Guan,Lamjung,Nepal. Norwegian University of Life Sciences, Ås.

Devkota, T. (2010). Retrieved 3 7, 2015, from Devkota .T (2010). Gorkhaparta-,,The Rising Nepal $^{\text {le }}$ Retrieved on February 2011, from: http://www.gorkhapatra.org.np/rising.detail.php?article_id=45767\&cat_id=7 .

Gangotia, A. (2013). Home Stay Scheme in Himachal Pradesh: A Succesful Story of Community Based Tourism Initiatives (CBTIS). Global Research Analysis, 2(2), 206-207.

Kreag, G. (2000). More than You Thought: The Impacts of Tourism. National Extension. Tourism 2000 Conference in Kailua-Kona Hawaii. Hawaii.

Laurie, N. D., \& Radcliffe, S. A. (2005). Working the Spaces of Neoliberalism: Activism, Professionalisation and Incorporation. In N. D. Laurie, \& L. Bondi, Ethnodevelopment: Social Movements, Creating Experts and Professionalising Indigenous Knowledge in Ecuador.

Perdue, R., Long, P., \& Allen, L. (1987). Rural resident tourism perceptions and attitudes. Annals of Tourism Research, 14, 420-429.

Ranjit, S. R. (1976). Tourist Industry with special reference to Foreign Exchange Earnings and Resort Development. M. A. Dissertaion. Kathmandu: Tribhuvan University.

Shrestha, H. P. (1998). Tourism Marketing in Nepal. Kathmandu: Tribhuvan University.

Timalsina, P. (2012). Homestay Tourism Boosts Ghale Gaon.s Economy. Retrieved 5 7, 2015, from http://www.gorkhapatra.org.np./rising.detail.php? Article_id=23200\&cat_id=4 